\title{
ANALISIS TINDAK TUTUR MENYATAKAN PENDAPAT DALAM DRAMA SERI “1 RITTORU NO NAMIDA"
}

\author{
Asteria Permata Martawijaya*) \\ STBA YAPARI-ABA Bandung \\ asteria@stba.ac.id
}

\begin{abstract}
ABSTRAK
Menyatakan pendapat merupakan tindak tutur yang dapat dianggap kurang sopan jika disampaikan dengan cara yang langsung. Oleh karena itu, saat mengemukakan pendapatnya orang Jepang sering kali menggunakan berbagai strategi tindak tutur dengan konstruksi yang bervariasi agar pendapatnya tidak terlalu tegas. Hal ini dilakukan dengan tujuan untuk menghormati dan menjaga perasaan petutur. Dalam penelitian ini, penulis mengkaji tindak tutur menyatakan pendapat dalam percakapan sehari-hari dengan melihat konstruksi yang digunakan dan maknanya. Penelitian ini dibatasi pada tindak tutur menyatakan pendapat atau fakta pada percakapan dalam drama seri 1 Rittoru no Namida. Metode yang digunakan adalah metode deskriptif. Dari hasil penelitian diketahui bahwa saat menyatakan pendapat atau fakta, penutur dalam drama seri 1 Rittoru no Namida menggunakan berbagai konstruksi. Konstruksi yang paling banyak digunakan yaitu konstruksi dugaan/ perkiraan. Selain itu digunakan pula konstruksi permintaan persetujuan, konstruksi penghindaran, konstruksi pertimbangan, dan konstruksi elipsis.
\end{abstract}

Kata kunci: tindak tutur, menyatakan pendapat, 1 Rittoru no Namida 
Expressing opinion is a speech act that can be considered unpolite if delivered in a direct speech. Therefore, when expressing their opinions Japanese people often use various speech act constructions so that their opinions are not too straight to the point. This is done in order to respect and maintain the interlocutor's feeling. In this study, the author examines speech acts expressing opinions in everyday conversation by looking at the construction used and its meaning. This research is limited to speech acts expressing opinions or facts in conversations on 1 Rittoru no Namida drama series. The method that used in this reseach is descriptive method. From the results of the study it was found that when expressing opinions or facts, speakers in the drama series 1 Rittoru no Namida used various constructions. The most widely used construction is guess construction. In addition, the construction of approval requests construction, avoidance construction, considerations construction, and elliptical construction are also used on the conversations.

Keywords: speech acts, expressing opinions, 1 Rittoru no Namida

\section{PENDAHULUAN}

Bahasa mempunyai fungsi sebagai sarana berlangsungnya interaksi manusia dalam masyarakat, karenanya saat kita berbicara dengan bahasa tertentu kita harus melakukannya dengan memperhatikan norma-norma yang berlaku dalam budaya dimana bahasa tersebut berasal. Tindak berbahasa menurut norma-norma budaya ini disebut "etika berbahasa" (Chaer, 1995: 226).

Penutur harus memahami kaidah-kaidah yang mengatur penggunaan bahasa dan interpretasinya terhadap ucapan petutur. Setiap peserta tindak tutur bertanggungjawab terhadap tindakan dan penyimpangan terhadap kaidah kebahasaan di dalam interaksi sosial (Wijana, 2004:28).

Austin (1962) dalam How to do Things with Words mengemukakan bahwa mengujarkan sebuah kalimat tertentu dapat dipandang sebagai melakukan tindakan (act), disamping memang mengucapkan kalimat 
tersebut. Ia membedakan tindakan yang berkaitan dengan ujaran menjadi tiga jenis, yaitu lokusi, ilokusi, dan perlokusi. Lokusi adalah semata-mata tindak berbicara, yaitu tindak mengucapkan sesuatu dengan kata dan kalimat sesuai dengan makna kata itu (di dalam kamus) dan makna kalimat itu sesuai dengan kaidah sintaksisnya. Ilokusi adalah tindak melakukan sesuatu. Sedangkan perlokusi mengacu ke efek yang ditimbulkan oleh ujaran yang dihasilkan oleh penutur. Tindak tutur ini disebut dengan the act of affecting someone. Secara singkat, perlokusi adalah efek dari tindak tutur itu bagi mitratutur.

Pemahaman akan lokusi, ilokusi dan perlokusi dalam tindak tutur dapat menentukan kualitas komunikasi seseorang. Apakah komunikasi yang dilakukan sesuai dengan tujuan berkomunikasinya atau tidak. Tujuan seseorang berkomunikasi kepada petutur adalah untuk menyampaikan pesan dan menjalin hubungan sosial (Rahardi, 2001:2). Pencapaian tujuan komunikasi untuk menjalin hubungan sosial tersebut dapat dilihat dari hubungan penggunaan ilokusi tertentu dengan perlokusinya. Hubungan antara ilokusi dan perlokusi ini berkaitan erat dengan konteks dimana proses komunikasi itu berlangsung.

Dalam bahasa Jepang, konteks tutur merupakan hal yang diperhatikan dalam komunikasi. Dimana penutur harus memperhatikan siapa petuturnya untuk menentukan tindak tutur yang digunakan dalam percakapan. Hal ini yang akhirnya membuat bahasa Jepang mempunyai nuansa pengungkapan yang berbeda dengan bahasa yang lain. Masyarakat Jepang memiliki keunikan dalam etika berbahasanya, yaitu masyarakat Jepang suka memutar-mutar kata sebelum masuk ke pokok penuturan, kadang tidak mengatakan inti percakapan secara eksplisit (terang-terangan) melainkan hanya secara tersirat untuk menimbulkan kenyamanan dan keramahan tanpa menyinggung orang lain (Edizal, 2001: 34). 
Hal ini berkaitan erat dengan penggunaan implikatur percakapan. Grice (1975; Kunjana, 2007) dalam artikelnya yang berjudul "Logic and Conversation" menyatakan bahwa sebuah tuturan dapat mengimplikasikan proposisi yang bukan merupakan bagian dari tuturan tersebut. Proposisi yang diimplikasikan itu dapat disebut dengan implikatur percakapan. Implikatur percakapan mengacu kepada jenis "kesepakatan bersama"antara penutur dan lawan tuturnya, kesepakatan dalam pemahaman, bahwa yang dibicarakan harus saling berhubungan. Hubungan atau keterkaitan itu sendiri tidak terdapat pada masing-masing ujaran. Artinya, makna keterkaitan itu tidak diungkapkan secara harafiah pada ujaran itu. Jadi, implikatur percakapan itu dapat dikatakan sejenis makna yang terkandung dalam cakapan yang dipahami oleh masing-masing partisipan.

Penggunaan implikatur dalam percakapan ini antara lain banyak terlihat pada saat penutur bahasa Jepang menyatakan pendapatnya kepada lawan tutur. Saat menyatakan pendapatnya, orang Jepang kadang menggunakan berbagai konstruksi strategi tindak tutur dalam tuturannya. Strategi tindak tutur adalah cara-cara yang digunakan partisipan tutur dalam mengekspresikan tindak atau fungsi tindak tutur menggunakan tuturan tertentu. Dalam kaitan ini, Brown dan Levinson (1978) mengatakan bahwa tuturan yang mengekspresikan tindak tutur pada umumnya menggambarkan strategi penyampaian tindak tutur tersebut. Tindak tutur dapat berbentuk langsung maupun tidak langsung, dan literal maupun tidak literal (Parker dalam Nadar, 2009: 17).

Blum-Kulka (1989) mengatakan bahwa strategi langsung dan tidak langsung yang digunakan dalam penyampaian tindak tutur berkaitan dengan dua dimensi, yaitu dimensi pilihan pada bentuk dan dimensi pilihan pada isi. Dimensi bentuk berkaitan dengan bagaimana suatu tuturan diformulasikan atau bagaimana ciri formal (berupa pilihan bahasa dan variasi linguistik) suatu tuturan dipakai 
untuk mewujudkan suatu ilokusi. Dimensi isi berkaitan maksud yang terkandung pada tuturan tersebut. Jika isi tuturan mengandung maksud yang sama dengan makna performasinya, maka tuturan tersebut dituturkan dengan strategi langsung. Sebaliknya, jika maksud suatu tuturan berbeda dengan makna performasinya maka tuturan tersebut dituturkan dengan strategi tidak langsung.

Menurut Kartomihardjo (1993), bahwa dalam hal-hal tertentu dalam sosial budaya tertentu, penggunaan strategi dengan tuturan langsung bukanlah perilaku yang baik karena mungkin akan menyakitkan hati orang lain. Bila perlu, mereka lebih baik menggunakan strategi dengan tuturan secara tidak langsung atau terselubung, dan membiarkan peserta tutur mengartikannya sendiri maksudnya. Strategi tidak langsung yang dimaksud dalam pandangan tersebut, dapat dikatakan sebagai strategi tidak langsung dengan maksud yang samar-samar atau strategi pengekspresian tindak tutur dengan maksud terselubung.

Penggunaan strategi tidak langsung dalam percakapan ini merupakan hal yang menarik untuk dikaji. Terlihat dari cukup banyaknya penelitian yang telah dilakukan berkenaan dengan hal ini. Misalnya, Beebe dan Takahashi (1989) melakukan studi untuk mengungkap realisasi pertuturan menolak yang dilakukan oleh penutur bahasa Jepang yang sedang belajar bahasa Inggris sebagai bahasa asing dengan pembanding orang Amerika. Demikian pula studi yang dilakukan oleh Ito (1989), yang menunjukkan adanya perbedaan realisasi pertuturan menolak yang dilakukan oleh orang Jepang bila dibandingkan dengan orang Amerika (Aziz, 2000). Realisasi tindak tutur orang Jepang tidak hanya dapat dilihat saat melakukan penolakan tapi juga digunakan saat orang Jepang menyatakan pendapat. Saat menyatakan pendapatnya, orang Jepang kadang menggunakan berbagai konstruksi strategi tindak tutur dalam tuturannya sehingga pernyataan pendapatnya tidak terdengar lugas. Penelitian mengenai strategi tindak tutur saat menyatakan pendapat ni masih jarang dilakukan. 
Dari permasalahan tersebut penulis tertarik untuk meneliti tindak tutur menyatakan pendapat yang digunakan dalam percakapan bahasa Jepang, yaitu meneliti konstruksi dan makna yang digunakan saat menyatakan pendapat atau fakta pada percakapan dalam drama seri 1 Rittoru no Namida. Dengan dilakukannya penelitian ini diharapkan dapat memberikan sumbangan pengetahuan bagi para pembelajar bahasa Jepang, khususnya mengenai penggunaan konstruksi tindak tutur menyatakan pendapat dalam percakapan bahasa Jepang.

\section{METODE PENELITIAN}

Metode yang digunakan dalam penelitian ini adalah metode deskriptif. Objek penelitian ini adalah tindak tutur menyatakan pendapat atau fakta pada percakapan dalam drama seri "1 Rittoru no Namida". Dengan menggunakan drama seri ini penulis dapat mengamati secara langsung penggunaan tindak tutur saat menyatakan pendapat oleh orang Jepang. Prosedur analisis data dalam penelitian ini meliputi beberapa tahapan yaitu tahap pengumpulan data, reduksi data, analisa data, penarikan kesimpulan dan penyajian hasil analisis.

\section{HASIL DAN PEMBAHASAN}

Tindak tutur menyatakan pendapat atau fakta pada percakapan film 1 Rittoru no Namida, adalah sebagai berikut :

\section{Percakapan 1}

父：ほら、ちょっとあけて見る、ほら、わあ〜。似合って る。(1)

Lihat, coba dipakai.. lihat.. wah.. cocok sekali.

亜湖 ：こんなださい着れると思ってるの。

Memangnya barang sejelek ini bisa dipakai? 
父：え?ださい?

Eh?Jelek?

亜也：家で着ればいいじやん。(3)

Kan bisa dipakai di rumah.

父：家?

Di rumah?

母：寝るときとか。(4)

Atau dipakai untuk tidur.

父：寝るとき?

Untuk tidur?

弘樹 ：セーターの下に着るとか。(5)

Atau dipakai di balik sweater.

父：セーターの下に?そんなにださいのか?

Di balik sweater? Memangnya sejelek itu ya?

Percakapan ini berlangsung di rumah, antara para anggota keluarga Aya. Karena adanya hubungan kekerabatan yang sangat erat maka ragam bahasa yang digunakan merupakan ragam biasa. Ayah membuatkan pakaian dengan model yang kuno untuk Ako dan memintanya untuk mencoba pakaian itu di hadapan keluarga. Lalu masing-masing anggota keluarga menyatakan pendapatnya mengenai baju tersebut. Ayah menyatakan pendapatnya dengan konstruksi pernyataan pendapat secara langsung, seperti terlihat pada kalimat (1). Ayah berpendapat bahwa baju tersebut cocok untuk Ako. Lalu Ako menyatakan pendapatnya dengan menggunakan konstruksi penghindaran berupa pertanyaan, seperti terlihat pada kalimat (2). Sementara Aya menyampaikan pendapatnya dengan konstruksi permintaan persetujuan, seperti terlihat pada kalimat (3). Hiroki dan Ibu menyampaikan pendapat mereka tentang baju tersebut dengan menggunakan konstruksi elipsis, seperti yang terlihat pada kalimat (4) 
dan (5). Mereka semua menyarankan Ako untuk menggunakan baju tersebut di rumah atau dibalik sweater sehingga tidak akan terlihat oleh orang lain. Hal ini secara tidak langsung menunjukkan pendapat mereka bahwa pakaian itu tidak cukup bagus untuk digunakan dan Ayah dapat menangkap maksud tersebut.

\section{Percakapan 2}

亜也：お店は?

Lalu bagaimana tokonya?

父：午後から開ければいいじやないか。(6)

Dibuka nanti siang juga tidak apa-apa kan.

母 ：午後から開けるとおとうふ屋さんどこいるのよ?(7)

Mana ada tukang tahu yang buka mulai siang hari?

父 : けど...

Tapi...

亜也：ねえ、お父さん、写真撮つて...(8)

Ayah, ayo kita berfoto bersama..

父：あ〜、そうだな。

Ah.. baiklah..

Percakapan ini terjadi di rumah antara Aya, Ibu, dan Ayah yang mempunyai pendapat berbeda tentang keputusan Ayah untuk menutup toko agar bisa hadir di upacara penerimaan siswa baru di sekolah Aya. Ragam bahasa yang digunakan adalah ragam biasa. Penggunaan tindak tutur tidak langsung saat menyatakan pendapat terlihat kalimat (6), (7) dan (8). Ayah menggunakan konstruksi permintaan persetujuan. Sedangkan ibu menggunakan konstruksi pertanyaan, yang membuat pendapat mereka berdua terkesan tidak tegas. Penggunaan tindak tutur tidak langsung saat menyatakan pendapat lain dapat dilihat pada kalimat (8), yaitu saat Aya mengungkapkan pendapatnya dengan 
konstruksi penghindaran berupa perubahan topik, yaitu dengan mengajak ayahnya untuk berfoto bersama.

\section{Percakapan 3}

亜也：吕とじや、まず指揮者を決めたいと思います。(9) terlebih dahulu.

Ehm.. baiklah, saya pikir sebaiknya kita memilih dirigen 富田： クラス員がやればいいと思います。(10)

Saya pikir sebaiknya itu dilakukan oleh ketua kelas.

Percakapan ini terjadi di sekolah. Saat Aya berdiri di depan kelas untuk mendiskusikan rencana untuk mengikuti lomba paduan suara bersama teman-temannya. Ragam bahasa yang digunakan ragam halus, terlihat dengan digunakannya konstruksi〜ます. Penggunaan tindak tutur tidak langsung saat menyatakan pendapat terlihat pada kalimat (9) dan (10). Aya dan Tomita menggunakan konstruksi bunmatsu yang menyatakan pertimbangan yaitu 〜 と思う, yang memberikan kesan tidak tegas saat mengungkapkan pendapat mereka.

\section{Percakapan 4}

亜也：病院?

Ke rumah sakit?

母：ちょっと気になるのよ。ほら、最近よく物を落とすでし よう。(11)それによく転ぶみたいだし...(12)

Ibu sedikit khawatir. Akhir-akhir ini kamu sering menjatuhkan barang kan. Selain itu, kamu juga kelihatannya sering jatuh..

亜也：たぶんちょつと疲れてるだけだって。(13)

Mungkin saya hanya terlalu lelah saja.

Percakapan ini terjadi di rumah, antara Ibu dan Aya. Ragam bahasa yang digunakan adalah ragam biasa. Ibu mengungkapkan 
pendapatnya akan kondisi kesehatan Aya dengan menggunakan tindak tutur tidak langsung. Seperti yang terlihat pada kalimat (11) dan (12). Ibu menggunakan konstruksi permintaan persetujuan 〜で しょうdan konstruksi dugaan 〜みたいだ yang menimbulkan kesan ketidakpastian sehingga pendapat yang diberikan terkesan tidak tegas. Sedangkan Aya menyatakan pendapatnya dengan menggunakan konstruksi dugaan yang ditandai dengan kata たぶん, seperti terlihat pada kalimat (13).

\section{Percakapan 5}

母：申し訳ありません、MRIの画像や検査データをお借りで きないでしょうか。昔から医者のはしごはしたほうがいい とお思いますし。。(14)

Maaf, bolehkah saya meminjam hasil CT scan dan hasil pemeriksaannya? Saya pikir akan lebih baik bila saya berdiskusi dengan dokter yang dari dulu biasa memeriksa Aya.

医者：セカンドオピニオンですか。

Untuk meminta pendapat kedua?

母：はい、できれば、ほかの先生の診断相見も伺いたいとお 思いまして $\ldots$

Iya, jika memungkinkan saya ingin menanyakan hasil diagnosis dari dokter yang lain.

Percakapan ini terjadi di rumah sakit, antara Ibu Aya dan Dokter Mizuno. Ragam bahasa yang digunakan adalah ragam halus. Penggunaan tindak tutur tidak langsung saat menyatakan pendapat terlihat pada kalimat (14), yaitu saat Ibu mengungkapkan pendapatnya dengan konstruksi bunmatsu yang menyatakan pertimbangan 〜 とお思いま すしsehingga pendapatnya tidak terdengar terlalu tegas. 


\section{Percakapan 6}

亜也：あたし、将来、将来ゆかちゃんのお父さんみたいになり ますか。教えてください、先生。

Apakah saya nanti.. nanti.. akan menjadi seperti ayah Yuki? Tolong beritahu saya dokter.

医者：ずっと先のことだけどね。なると思う。

Masih lama sekali sebelum hal itu terjadi. Tapi ya, kau akan menjadi seperti itu.

Percakapan ini terjadi di rumah sakit, antara Aya dan Dokter. Ragam bahasa yang digunakan adalah ragam biasa. Penggunaan tindak tutur tidak langsung saat menyatakan pendapat terlihat pada kalimat (15), yaitu saat Dokter mengungkapkan dengan konstruksi bunmatsu yang menyatakan pertimbangan 〜 と思うsehingga pendapat itu tidak terkesan tegas.

\section{Percakapan 7}

母：本当に知らせてよかったと思う。病気のことは本当に受 け止められるまで、あの子すごく苦しむと思う。(16) ぱり、もつと様子見てからにすれば...(17)

Saya pikir untunglah kita memberitahunya. Bila menunggu sampai dia bisa menerima penyakitnya, anak itu pasti sangat sedih. Tapi tetap, kalau saja kita memberinya waktu sedikit...

Percakapan ini terjadi di rumah, antara Ayah dan Ibu. Mengingat kedekatan antara keduanya maka tak heran jika ragam bahasa yang digunakan adalah ragam biasa. Penggunaan tindak tutur tidak langsung saat menyatakan pendapat terlihat pada kalimat (16), yaitu saat Ibu mengungkapkan pendapatnya dengan menambahkan konstruksi bunmatsu yang menyatakn pertimbangan 〜 と思う. Selain itu, saat menyatakan pendapat penutur juga menggunakan konstruksi elipsis, yaitu dengan menghentikan kalimat setelah kata 〜すれば, sehingga pendapat tidak terlihat tegas, seperti yang terlihat pada kalimat (17). 


\section{Percakapan 8}

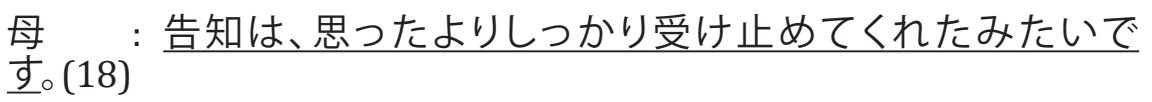

Di luar dugaan, sepertinya dia bisa menerima pemberitahuan itu dengan tabah.

Percakapan ini terjadi di rumah sakit, antara ibu dan Dokter Mizuno. Ragam bahasa yang digunakan adalah ragam halus. Penggunaan tindak tutur tidak langsung saat menyatakan pendapat terlihat pada kalimat (18), yaitu saat Ibu mengungkapkan pendapatnya tentang kondisi Aya dengan menggunakan konstruksi dugaan 〜みたいです yang memberikan kesan bahwa pendapatnya tidak terlalu pasti.

\section{Percakapan 9}

医者：この病気は人によって症状や進行の程度が大きく違いま すが。亜也さんの場合、進行が早いようです。(19) なるべ く、早く亜也さんは適切薬するや、レハビリ方法見つける 必要があります。やはり、夏休みを利用して、検査入院さ れてはいかがでしょうか。

Gejala dan tingkat perkembangan penyakit ini berbeda-beda pada setiap orang. Untuk Aya sepertinya perkembangannya sangatcepat. Jika memungkinkan, perlu secepatnya menemukan obat dan cara rehabilitasi yang tepat. Bagaimana kalau memanfaatkan libur musim panas ini untuk opname di rumah sakit?

Percakapan ini berlangsung di rumah sakit, antara Dokter Mizuno dan Ayah. Karena adanya hubungan profesional, maka ragam bahasa yang digunakan adalah ragam halus. Penggunaan tindak tutur tidak langsung saat menyatakan pendapat terlihat pada kalimat (19), yaitu saat Dokter Mizuno mengungkapkan pendapatnya mengenai kondisi Aya dengan menggunakan konstruksi dugaan 〜ようです yang mengesankan ketidakpastian. Padahal sebagai seorang dokter tentunya dia mengetahui jelas kondisi pasien yang sebenarnya. Selain itu, saat mengemukakan pendapatnya Dokter Mizuno menggunakan 
konstruksipenghindaran seperti terlihat pada kalimat (20). Beliau tidak menyatakan pendapatnya mengenai efek pengobatan secara pasti, tapi menghindar berpendapat dengan menyatakan bahwa dia tidak bisa menyatakan apa-apa sebelum proses pengobatan Aya dilakukan.

\section{Percakapan 10}

母：あのね、少し貯金崩そうと思ってるんだけど...

Begini... sepertinya saya perlu menggunakan sebagian uang tabungan kita.

父： 何言ってるんだよ、ただのスパイクぐらいでもよ。 kets.

Apa maksudmu, bukankah Hiroki hanya akan membeli sepatu

母：亜也あしたからタクシーで登校させようと思ってる 正。(21)

Saya pikir mulai besok sebaiknya Aya berangkat ke sekolah dengan menggunakan taksi.

父：亜也、そんなに悪いのか。 Apakah kondisi Aya separah itu?

母：そうじやなくてね、みずの先生もなるべく今まで通りつ ておしやつたんだけど、でもまだ、もし転んでも、けがで もしたらと思って。。(22)

Bukan begitu.. Sebenarnya dokter Mizuno mengatakan bahwa akan lebih baik bila membiarkan keadaan berjalan seperti biasanya, tapi tetap saja... bagaimana kalau Aya jatuh dan terluka...

父：わかった、亜也はタクシーで通わせよう。

Baiklah, kita akan menyuruh Aya menggunakan taksi ya..

Percakapan ini berlangsung di rumah, antara Ibu dan Ayah. Ragam bahasa yang digunakan adalah ragam biasa. Penggunaan tindak tutur tidak langsung saat menyatakan pendapat terlihat pada kalimat (21) 
dan (22) Ibu menggunakan konstruksi〜 と思つてdiakhir kalimat, untuk menimbulkan kesan tidak tegas akan pendapatnya.

\section{Percakapan 11}

亜湖：亜也ねえ、ぜんぜんよくなってないじやん。入院までし たのに、こんなのおかしいじゃん。(23)

Kak Aya kok belum sembuh juga ya. Padahal sudah sampai masuk ke rumah sakit, bukankah hal ini aneh?

母：治るには少し時間がかかるみたい。(24) sembuh.

Sepertinya dia membutuhkan lebih banyak waktu untuk

Percakapan ini terjadi di rumah antara Ako dan Ibunya. Ragam bahasa yang digunakan adalah ragam biasa. Penggunaan tindak tutur tidak langsung saat menyatakan pendapat terlihat pada kalimat (23) dan (24). Ako menyatakan pendapatnya dengan konstruksi permintaan persetujuan, sedangkan Ibu menggunakan konstruksi dugaan 〜みた いsaat mengungkapkan pendapatnya tentang kondisi kesehatan Aya, sehingga pendapat yang diungkapkan tidak terdengar terlalu tegas.

\section{Percakapan 12}

遥斗の母 : 遥斗、やつと勉強する気になつたみたい。(25)

belajar.

Sepertinya Haruto mulai mempunyai semangat untuk 遥斗の父 : へえ?

\section{Benarkah?}

Percakapan ini terjadi di rumah antara Ayah Haruto dan ibu Haruto. Ragam bahasa yang digunakan adalah ragam biasa. Penggunaan tindak tutur tidak langsung saat menyatakan pendapat terlihat pada kalimat (25), yaitu dengan digunakannya konstruksi dugaan 〜みたい pada saat Ibu mengungkapkan pendapatnya tentang Haruto yang menjadi rajin belajar, sehingga pendapat yang diungkapkan tidak terdengar terlalu tegas. 


\section{Percakapan 13}

母： 最近は日用毎に前向きになってみたいです。(26)

Kelihatannya sekarang dia lebih optimis.

医者：そうですか。

Benarkah?

Percakapan ini terjadi di rumah sakit, antara Dokter Mizuno dan ibu. Ragam bahasa yang digunakan adalah ragam halus. Penggunaan tindak tutur tidak langsung saat menyatakan pendapat terlihat pada kalimat (26) yaitu dengan digunakannya dugaan konstruksi〜みた い pada saat Ibu mengungkapkan pendapatnya tentang Aya yang semakin terlihat optimis, sehingga pendapat yang diungkapkan tidak terdengar terlalu tegas.

\section{Percakapan 14}

母 : どうでしょうか。

\section{Bagaimana Dok?}

医者：もしもみだれはそれほど進行してないみたいです ね。(27) buruk.

Sepertinya penyakitnya belum berkembang ke arah yang lebih 母

$$
\begin{aligned}
& \text { : 今度の薬は亜也に合ってたようで、以前より調子がいい } \\
& \text { ようにと思います。(22) } \\
& \text { じやないかって思えたりするぐらいで。もしかたらこのま } \\
& \text { ま...先生?(28) }
\end{aligned}
$$

Karena obat yang Aya makan sekarang, sepertinya kondisi Aya menjadi lebih baik dari sebelumnya. Mungkinkah bila terus seperti ini Aya akan bisa sembuh. Bila terus seperti ini... Dokter?

Percakapan ini terjadi di rumah sakit, antara Dokter Mizuno dan ibu. Ragam bahasa yang digunakan adalah ragam halus. Penggunaan tindak tutur tidak langsung saat menyatakan pendapat terlihat pada kalimat (27), yaitu dengan digunakannya konstruksi dugaan 〜みたい pada 
saat Dokter Mizuno mengungkapkan pendapatnya tentang kondisi kesehatan Aya. Selain itu, tindak tutur tidak langsung juga digunakan pada kalimat (28), yaitu dengan digunakannya konstruksi bunmatsu yang menyatakan pertimbangan 〜と思いますdan konstruksi dugaan もしかしたら saat Ibu mengungkapkan pendapatnya, sehingga pendapat yang diungkapkan tidak terdengar terlalu tegas.

\section{Percakapan 15}

教徒：池内さん、養護学校に行かれることお考えになったこと はありますか。養護学校でしたら、娘さんに状態に応じ て、適切なタイムをしてくれるはずです。今のように、教 室の移動で苦労することもないでしょうし、他の生徒に負 担のかけることもないでしよう。(29)

Ikeuchi san, apakah anda pernah mempertimbangkan untuk pergi sekolah luar biasa? Sekolah luar biasa tentunya akan lebih sesuai dengan kondisi putri anda, disana disediakan waktu yang lebih banyak, sehingga putri anda tidak perlu lagi bersusah payah berpindah-pindah kelas seperti saat ini dan murid lain pun tidak perlu merasa terbebani lagi.

Percakapan ini berlangsung di sekolah dalam suasana yang cukup formal, maka ragam bahasa yang digunakan pun adalah ragam halus. Penggunaan tindak tutur tidak langsung saat menyatakan pendapat terlihat pada kalimat (29). Kyoto Sensei menyampaikan pendapatnya dengan menggunakan konstruksi permintaan persetujuan 〜でしょ うsehingga pendapat yang disampaikan terdengar tidak terlalu tegas.

\section{Percakapan 16}

女1：もしうちの子お手伝いしてる時に、何があったらと思つ たら、心配でしょうがないんですよ。

Kadang saya berpikir bagaimana kalau anak saya sampai terluka saat menolong Aya, saya merasa sangat cemas tapi saya juga tidak bisa melakukan apa-apa.

女2：責任なんて取れませんし。

Tapi bukan berarti kami menyalahkan Ibu. 
男1： まあ、同じ親としては、応援してあげたいという気持ち もありますけどね。(30)

Ya, sebagai sesama orang tua, tentunya kita juga ingin memberikan dukungan bukan?

女3 : 池内さんがお子さんの子とを思われる同じように、あた したちも自分の子供が心配なんです。

Sama seperti Ibu Ikeuchi memikirkan putri Ibu, kami juga mengkhawatirkan anak kami.

母：それはその通りだと思います。

Hal itu sudah sewajarnya.

女3 : でしたら

Karenanya...

女4:

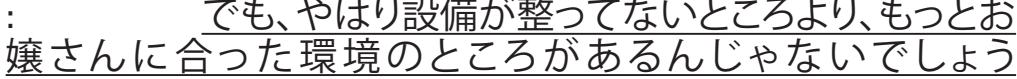
か。(32)

Tapi, dari pada bertahan di tempatyang tidak bisa memberikan fasilitas yang baik, bukankah ada tempat lain yang suasananya lebih baik untuk putri anda?

Percakapan ini berlangsung di sekolah, saat rapat POMG diadakan. Pertemuan ini bersifat formal maka ragam bahasa yang digunakan pun ragam halus. Penggunaan tindak tutur tidak langsung saat menyatakan pendapat terlihat pada kalimat (30). Bapak pertama mengungkapkan pendapatnya dengan menggunakan konstruksi bunmatsu penyangkalan 〜けど. Sehingga pendapatnya terkesan ragu-ragu dan tidak tegas. Pada kalimat (31) Ibu ketiga menyatakan pendapatnya dengan konstruksi elipisis, dengan tidak menyelesaikan kalimatnya secara utuh guna menghaluskan pendapat yang diutarakannya. Selain itu, tindak tutur tidak langsung juga digunakan pada kalimat (32). Ibu keempat menggunakan konstruksi permintaan persetujuan berupa じやないでしょうか pada saat mengungkapkan pendapatnya. 


\section{Percakapan 17}

中原: 池内さん、可愛そうでしょう。五分とか十分ぐらい待って あげましようよ。(33)

Kasihan ya Ikeuchi. Mari kita beri waktu barang lima atau sepuluh menit ya?

富田: 杉浦さんたちはどうですか?

Bagaimana pendapat Sugiura dan kawan-kawan?

まり：＼cjkstart亜也は、いろいろ悩んで、でも必死ですでく頑張ってるん だよ。ほんの少し支えてあげるくらい、迷惑にはならない でしよう?(34)

Aya telah banyak mengalami kesulitan tapi dia berjuang matimatian. Kalau hanya sekedar memberi dukungan tentunya tidak akan menyusahkan bukan?

友 1：でも、杉浦さん、池内のせいで、怪我して、バスケの試合出 られなかつたんだよね。

Tapi karena membantu Aya kau jadi terluka dan tidak dapat mengikuti pertandingan basket bukan?

まり : それは、そうだけど… (35)

Itu benar, tapi kan...

Percakapan ini terjadi di kelas, saat seluruh kelas sedang berdiskusi mengenai masalah Aya. Ragam bahasa yang digunakan adalah ragam biasa. Penggunaan tindak tutur tidak langsung saat menyatakan pendapat terlihat pada kalimat (33) saat Takahara mengungkapkan pendapatnya dengan menggunakan konstruksi permintaan persetujuan 〜でしょう dan あげましょうよyang menimbulkan kesan tidak tegas. Selain itu, tindak tutur tidak langsung juga digunakan pada kalimat (34) saat Mari mengungkapkan pendapatnya dengan menggunakan konstruksi permintaan persetujuan 〜でしょ う sehingga pendapatnya terdengar tidak tegas. Dan pada kalimat (35) saat Mari mengungkapkan pendapatnya dengan konstruksi elipsis, yaitu tidak menyelesaikan kalimatnya sampai tuntas. 


\section{Percakapan 19}

母

\section{: 歩けるところはなるべく自分で歩くって言ってたけど、 一人で自由に動く喜びは大きいみたい。(36)}

Meskipun dia berkata selama masih bisa berjalan, dia akan terus berusaha untuk berjalan. Tapi sepertinya dia juga sangat senang karena dapat bergerak dengan bebas.

父：そうかな...

Begitu ya..

母：養護学校持っていけば、活動範囲も広がると思う

Kalau kita membawa kursi roda listrik ini ke sekolah luar biasa, tentu ruang geraknya akan lebih luas.

父：あ、でも、やっぱり心配なあ…寄宿舎生活っていうの よ。だってあいつ、案外徖しがりやだろう?(38)

Ah, tapi, saya tetap merasa khawatir. Itu kan kehidupan asrama. Kalau begitu dia mungkin akan merasa kesepian kan?

母

: 大丈夫よ。うん、大丈夫。だって、あの子が自分の決め たことだもの。私たちが笑って送り出さないと、どうする のよ。

Tidak apa-apa. Pasti dia akan baik-baik saja. Ini kan keputusannya sendiri. Apalagi yang bisa kita lakukan selain melepasnya pergi dengan senyuman?

父：そうだな。

Iya, kau benar.

Percakapan ini terjadi di rumah, Ayah dan Ibu berbincang dengan menggunakan ragam biasa. Penggunaan tindak tutur tidak langsung saat menyatakan pendapat terlihat pada kalimat (36), yaitu dengan digunakannya konstruksi dugaan 〜みたい. Tindak tutur tidak langsung juga digunakan pada kalimat (37), yaitu penggunaan konstruksi〜 と思うdiakhir kalimat. Selain itu, tindak tutur tidak langsung juga digunakan pada kalimat (38), saat ayah menggunakan konstruksi permintaan persetujuan 〜だろうuntuk mengungkapkan pendapatnya. 


\section{Percakapan 20}

あいかわ：デートーの約束だ。彼氏?

Janji kencan ya. Itu pacarmu?

亜也 ：違います、高校のクラスメート。

Bukan. Dia teman sekelasku di SMA.

あいかわ：違うんだ。いつも携帯そばに置いて、鳴るのを待つ てるみたいだから。(39)

Bukan ya. Padahal kelihatannya kau selalu menaruh handphone di sebelahmu dan menunggunya berbunyi.

Percakapan ini terjadi di kamar asrama, antara Aya dan teman sekamarnya, Aikawa. Ragam bahasa yang digunakan adalah ragam biasa. Penggunaan tindak tutur tidak langsung saat menyatakan pendapat terlihat pada kalimat (39) yaitu dengan digunakannya konstruksi dugaan 〜みたいpada saat Aikawa mengungkapkan pendapatnya.

\section{Percakapan 21}

遥斗の父：亜也さんのご様子はいかがですか？

Bagaimana kondisi Aya?

母

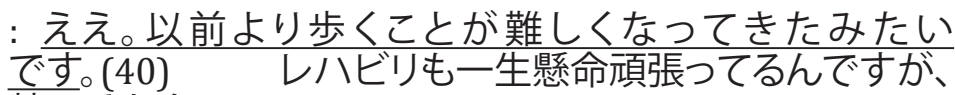
特にそれも... (41)

Ehm, kalau dibandingkan dengan kondisi sebelumnya, saat ini sepertinya dia mengalami lebih banyak kesulitan saat berjalan. Walaupun dia sangat bersemangat melakukan rehabilitasi, tapi sepertinya..

遥斗の父：そうですか。

Begitu ya.

母

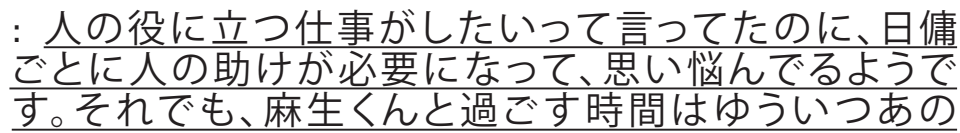




\section{子の心の支えになつているようです。(42)}

Walaupun dia berkata ingin melakukan pekerjaan yang berguna bagi orang lain, tapi dia harus menerima bantuan orang lain untuk melakukan pekerjaan sehari-hari, hal itu tentunya membuatnya galau. Tapi meskipun begitu, waktu yang dia habiskan bersama Aso merupakan satu-satunya hal yang bisa menghibur hatinya.

遥斗父：いや、こちらこそ。亜也さんのおかげで、あいつは 変わりました。目標見つけて、前よりずつと楽しそう です。(43)

Tidak, seharusnya saya yang mengucapkan terima kasih. Berkat Aya, Haruto menjadi berubah. Setelah dapat menemukan tujuan hidupnya, kelihatannya Haruto lebih bahagia sekarang.

Percakapan initerjadi dijalan, saat Ibu Aya bertemu dengan Ayah Haruto. Ragam bahasa yang digunakan adalah ragam halus karena hubungan antara keduanya tidak terlalu akrab. Penggunaan tindak tutur tidak langsung saat menyatakan pendapat terlihat pada kalimat (40) yaitu dengan digunakannya konstruksi dugaan 〜みたい dan konstruksi elipsis pada kalimat (41) saat Ibu mengungkapkan pendapatnya tentang kondisi Aya. Selain itu, tindak tutur tidak langsung pun digunakan pada kalimat (42) yaitu dengan menggunakan konstruksi dugaan 〜ようですpada saat Ibu mengungkapkan pendapatnya. Dan pada kalimat (43) dengan digunakannnya konstruksi dugaan 〜そう です saat Ayah Haruto menyatakan pendapatnya tentang Haruto.

\section{Pembahasan}

Berdasarkan analisis mengenai konstruksi dan makna penggunaan tindak tutur tidak langsung saat menyatakan pendapat yang terdapat pada percakapan dalam film 1 Rittoru no Namida, dapat diketahui bahwa terdapat berbagai konstruksi yang digunakan saat penutur menyatakan pendapat atau fakta : 
a. Permintaan Persetujuan

Pernyataan pendapat dengan menggunakan konstruksi permintaan persetujuan pada percakapan dalam drama seri 1 Rittoru no Namida cukup banyak ditemukan. Ada empat kalimat yang menggunakan pola 〜じやないか, empat kalimat yang menggunakan pola 〜でし よう, dan satu kalimat menggunakan pola 〜だろう.

b. Penghindaran

Dari data peneliti juga menemukan penggunaan konstruksi penghindaran saat penutur menyatakan pendapat atau fakta pada percakapan dalam drama seri 1 Rittoru no Namida. Strategi yang dilakukan adalah dengan mengganti topik penuturan (satu kalimat), menunda pernyataan pendapat (satu kalimat) dan dua kalimat menggunakan konstruksi penghindaran berupa sindiran.

c. Pertimbangan

Pernyataan pendapat dengan menggunakan konstruksi pertimbangan pada percakapan dalam drama seri 1 Rittoru no Namida pun cukup banyak ditemukan. Ada sembilan buah kalimat pengungkapan pendapat dengan konstruksi bunmatsu yang menyatakan pertimbangan 〜 と思う.

d. Dugaan/ perkiraan

Konstruksi dugaan merupakan konstruksi yang paling banyak digunakan pada percakapan dalam darama seri 1 Rittoru no Namida. Ditemukan 17 contoh kalimat menyatakan pendapat atau fakta yang menggunakan konstruksi ini. Pola yang digunakan meliputi 〜みたいだ (sembilan kalimat), たぶん (satu kalimat), 〜 ようだ (2 kalimat), もしかしたら (satu kalimat) dan 〜そうです (satu kalimat). 
e. Elipsis

Pernyataan pendapat dengan menggunakan konstruksi elipsis pada percakapan dalam drama seri 1 Rittoru no Namida yaitu meliputi lima buah kalimat yang tidak diselesaikan hingga tuntas.

Penjelasan singkat mengenai konstruksi kalimat yang mengandung tindak tutur tidak langsung saat menyatakan pendapat atau fakta pada percakapan dalam film 1 Rittoru no Namida berdasarkan klasifikasi bentuknya disajikan dalam tabel berikut:

\section{Tabel 1}

\section{Penggunaan Tindak Tutur Tidak Langsung Saat Menyatakan Pendapat atau Fakta pada Percakapan dalam Drama Seri 1 Rittoru no Namida}

\begin{tabular}{|c|c|c|c|}
\hline No & $\begin{array}{c}\text { Konstruksi yang } \\
\text { digunakan }\end{array}$ & Pola Kalimat & Contoh Kalimat \\
\hline 1 & $\begin{array}{l}\text { Permintaan } \\
\text { persetujuan }\end{array}$ & $\begin{array}{l}\text { ～じやないか } \\
\text { ～でしょう } \\
\text { ～だろう }\end{array}$ & $\begin{array}{l}4 \text { kalimat }(3,6,23,32) \\
4 \text { kalimat }(11,29,33,34) \\
1 \text { kalimat }(38)\end{array}$ \\
\hline \multirow[t]{3}{*}{2} & \multirow[t]{3}{*}{ Penghindaran } & Mengganti topik & 1 kalimat (8) \\
\hline & & Menunda & 1 kalimat (20) \\
\hline & & Pertanyaan & 2 kalimat $(2,7)$ \\
\hline 3 & Pertimbangan & 〜と思う & $\begin{array}{l}9 \text { kalimat }(9,10,14,15,16,21 \text {, } \\
22,28,37)\end{array}$ \\
\hline \multirow[t]{5}{*}{4} & \multirow[t]{5}{*}{$\begin{array}{l}\text { Dugaan/ } \\
\text { perkiraan }\end{array}$} & 〜みたいだ & $\begin{array}{l}9 \text { kalimat }(12,18,24,25,26,27 \text {, } \\
36,39,40)\end{array}$ \\
\hline & & たぶん & 1 kalimat (13) \\
\hline & & 〜ようだ & 2 kalimat $(19,42)$ \\
\hline & & もしかしたら & 1 kalimat (28) \\
\hline & & 〜そうです & 1 kalimat (43) \\
\hline 5 & Elipsis & $\begin{array}{l}\text { Tidak menyelesaikan } \\
\text { kalimat }\end{array}$ & 5 kalimat $(4,5,30,31,35)$ \\
\hline
\end{tabular}




\section{SIMPULAN}

Dari hasil analisis dapat diketahui bahwa penggunaan tindak tutur tidak langsung saat menyatakan pendapat atau fakta memiliki bermacam-macam konstruksi pengungkapan. Pada situasi mengungkapkan pendapat atau fakta pada percakapan dalam film 1 Rittoru no Namida terdapat 5 konstruksi yang digunakan. Konstruksi yang paling banyak digunakan yaitu konstruksi dugaan/ perkiraan. Selain itu, digunakan pula konstruksi permintaan persetujuan, konstruksi penghindaran, konstruksi pertimbangan, dan konstruksi elipsis. Penggunaan kontruksi-kontruksi tersebut dimaksudkan agar pernyataan pendapat atau fakta tidak terdengar terlalu tegas, guna menjaga perasaan petutur.

\section{DAFTAR PUSTAKA}

Austin, J.L. 1962. How To Do Things With Words. Oxford: Oxford University Press.

Aziz, Aminudin E. 2000. "Aspek-aspek Budaya yang Terlupakan dalam Praktek Pengajaran Bahasa Asing". Bandung: Universitas Pendidikan Indonesia.

Blum-Kulka, S., House, J., \& Kasper, G. 1989. Cross-cultural Pragmatics: Requestand Apologies. Norwood, NJ: Albex Publishing Corporation.

Brown, P., \& Levinson, S. 1978. Universals of Language Usages: Politeness Phenomena; in: Esther Goody (ed.), Questions and Politeness Strategies in Social Interaction. Cambridge: Cambridge University Press, 56-311.

Chaer, Abdul \& Agustina, Leonie. 1995. Sosiolingusitik Perkenalan Awal. Jakarta: Rineka Cipta. 
Edizal. 2001. Tutur Kata Manusia Jepang. Padang: Kayu Pasak.

Kartomihardjo, S. 1993. “Analisis Wacana dengan Penerapannya pada Beberapa Wacana" dalam Bambang Kaswanti Purwo (Ed.). PELIBA 6. Jakarta: Lembaga Bahasa Unika Atma Jaya.

Nadar, F. X. (2009). Pragmatik dan Penelitian Pragmatik. Yogyakarta: Graha Ilmu.

Rahardi, Kunjana. 2001. Alih Kode dan Campur Kode. Yogyakarta: Pustaka Pelajar

Rahardi, Kunjana. 2002. Sosiopragmatik. Jakarta: Erlangga.

Rahardi, Kunjana. 2007. Pragmatik: Kesantunan Imperatif Bahasa Indonesia. Jakarta : Erlangga.

Tarigan, Guntur. 1990. Pengajaran Pragmatik. Bandung: Angkasa.

Wijana, Putu. 1996. Dasar-Dasar Pragmatik. Yogyakarta: ANDI.

Wijana, I Dewa Putu. 2004. Dasar-Dasar Pragmatik. Yogyakarta: Andi offset. 